\title{
Antibacterial Activity of Ginger (Zingiber officinale) Leaves Essential Oil Nanoemulsion against the Cariogenic Streptococcus mutans
}

\author{
Nada M. Mostafa \\ Department of Pharmacognosy, Faculty of Pharmacy, Ain Shams University, Cairo, Egypt.
}

\begin{tabular}{l}
\hline ARTICLE INFO \\
\hline Article history: \\
Received on: $23 / 02 / 2018$ \\
Accepted on: 11/07/2018 \\
Available online: $30 / 09 / 2018$ \\
\\
\hline Key words: \\
Zingiber officinale, essential \\
oil, GC/MS, Streptococcus \\
mutans, molecular docking.
\end{tabular}

\section{INTRODUCTION}

Zingiber officinale Roscoe (family Zingiberaceae) is widely cultivated for its medicinal uses and as a condiment. It is used traditionally to treat the common cold, headache, muscular and rheumatic disorders (Yang et al., 2009). Numerous studies have investigated the phytochemical composition of its rhizomes, revealing zingiberene, gingerol, shogaol and their derivatives as the major components (Sivasothy et al., 2011). Reported pharmacological activities on ginger include antimicrobial, antioxidant, anti-inflammatory, hepatoprotective and antinociceptive (Abdel Azeem et al., 2013; Jeena et al., 2013; Mostafa and Singab, 2016).

Nanoemulsions are emulsions with sub-micron size that can be produced by either high- or low-energy method. The high energy method involves the application of high-pressure

\footnotetext{
${ }^{*}$ Corresponding Author

Nada M. Mostafa, Assistant Professor, Department of Pharmacognosy, Faculty of Pharmacy, Ain Shams University, Cairo 11566, Egypt. E-mail:nadamostafa@pharma.asu.edu.eg
}

homogenization or micro-fluidization, while the low energy method involves continuous stirring of a mixture of oil, water, and surfactant, without any drastic condition or expensive equipment (Salama et al., 2016). The choice of the suitable surfactant is important, such as Tween-80, which is a low molecular weight non-ionic surfactant commonly used in food and pharmaceutical products (Salama et al., 2016; Nielsen et al., 2016).

The encapsulation of an essential oil in a nanoemulsion form, protects its thermolabile components, that are also sensitive to the effects of light, moisture, and air and guarantees significant decrease in their volatility, increase of their bioavailability and efficacy as a result of increasing the surface area and stability of the particles (Amaral and Bhargava, 2015; Nantarat et al., 2015).

Dental caries is an oral infection manifested by teeth enamel demineralization and destruction (Hasan et al., 2014). Its main causative agent is Streptococcus mutans, which is a colonizing and biofilm-forming bacterium with a high ability to adhere to solid surfaces (Krzyściak et al., 2014). These properties may be attributed to the bacterial ability to survive and tolerate the acids produced as a result of oral carbohydrate metabolism (Hasan 
et al., 2015). Dental plaque is the aggregate bacterial accumulation on the surface of teeth, where Streptococcus mutans is involved in its development and accumulation (Loesche, 1986).

The aim herein is profiling the volatile components of Zingiber officinale leaves, for the first time, from the Egyptian plant; testing the stability, anticariogenic and antiplaque effects of a formulated nanoemulsion of the ginger leaves essential oil against Streptococcus mutans, which was carried out for the first time as well. The antimicrobial and antibiofilm-forming activities were supported by transmission electron microscope imaging and an in-silico molecular docking study.

\section{MATERIALS AND METHODS}

\section{Plant material}

Leaves of Zingiber officinale Roscoe, family Zingiberaceae were collected from El-Orman Botanical Garden, Cairo, Egypt. Identification of the plant was confirmed by Prof. Dr. Mohamed El Gebaly, Professor of Taxonomy, National Research Centre, Egypt. A voucher specimen was deposited at the Department of Pharmacognosy, Faculty of Pharmacy, Ain Shams University, Abbassia, Cairo, Egypt (PHG-P-ZO-1).

\section{Isolation of volatile component}

Fresh plant material $(1 \mathrm{Kg})$ was hydrodistilled in a Clevenger-type apparatus for 4 hours. The resulting yellow oil $(0.15 \% \mathrm{v} / \mathrm{w})$ was then dried over anhydrous sodium sulfate and kept in separately sealed vials at $-30^{\circ} \mathrm{C}$ until analysis.

\section{Essential oil GC-MS analysis}

The mass spectrum was recorded by using Shimadzu GC MS-QP2010 (Tokyo, Japan) equipped with Rtx-5MS fused bonded column $(30 \mathrm{~m} \times 0.25 \mathrm{~mm}$ i.d. $\times 0.25 \mu \mathrm{m}$ film thickness $)$ (Restek, USA) and a split-splitless injector. The capillary column was directly coupled to a quadrupole mass spectrometer (SSQ 7000; Thermo-Finnigan, Bremen, Germany). The initial column temperature was kept at $45^{\circ} \mathrm{C}$ for 2 minutes (isothermal), programmed to $300^{\circ} \mathrm{C}$ at a rate of $5^{\circ} \mathrm{C} / \mathrm{min}$ and kept constant at $300^{\circ} \mathrm{C}$ for 5 minutes (isothermal). The helium carrier gas flow rate was $1.41 \mathrm{~mL} / \mathrm{min}$. The injector temperature was $250^{\circ} \mathrm{C}$. The mass spectrum was recorded by applying filament emission current of $60 \mathrm{~mA}$, ionization voltage of $70 \mathrm{eV}$, and $200^{\circ} \mathrm{C}$ ion source. A diluted sample $(1 \% \mathrm{v} / \mathrm{v})$ was injected with split mode with a split ratio of $1: 15$.

\section{Nanoemulsion formulation}

The nanoemulsion was prepared by spontaneous emulsification, composed of essential oil ( $1 \% \mathrm{v} / \mathrm{v})$; water phase containing Tween-80 $(4.5 \% \mathrm{v} / \mathrm{v})$; then the water was added to complete the volume to $100 \% \mathrm{v} / \mathrm{v}$. It was kept under moderate magnetic stirring for $5 \mathrm{~min}$ at room temperature. The surfactant percentage was determined after several trial and error experiments until reaching a visually homogenous emulsion with no phase separation.

\section{Nanoemulsion characterization}

Particle size, PDI, zeta potential and pH determinations

The particle size, polydispersity index (PDI) and charge of the prepared nanoemulsion were measured (in triplicates) by photon correlation spectroscopy (based on dynamic light scattering), using Zetasizer NanoZS 3600 (Malvern Instruments Ltd., Worcestershire, UK), after adequate aliquot dilution of the samples in distilled water (Manconi et al., 2011). The $\mathrm{pH}$ values of the nanoemulsion were determined (in triplicate) directly using a $\mathrm{pH}$ meter (Jenway $\mathrm{pH}$ meter, Model 3310, UK) at room temperature.

\section{Stability study for the prepared vesicles}

The prepared nanoemulsion was stored for one month at a refrigeration temperature of $2-8^{\circ} \mathrm{C}$. During the storage period, the sample was regularly inspected visually for its homogeneity and consistency. The particle size, zeta potential, and polydispersity index (PDI) of the nanoemulsion were also re-measured.

\section{Morphological analysis by transmission electron microscope (TEM)}

The nanoemulsion, after appropriate dilution with distilled water, was adsorbed on a carbon-coated copper grid. Then, particles morphology and size were examined and photographed using a JEM 1200 EXII transmission electron microscope, Jeol, Japan, operated at an accelerating voltage of $60-70 \mathrm{KV}$.

\section{Antimicrobial activity}

Microbial strain

The nanoemulsion was tested against Streptococcus mutans ATCC 25175.

\section{Agar diffusion method}

S. mutans inoculum (density of $0.5 \%$ McFarland) was spread on the surface of Brain Heart Infusion agar (Lab M, UK), then tested via the agar diffusion method, according to CLSI methodology (2013). A negative control (containing Tween-80) was prepared as the nanoemulsion but without the essential oil. Ready discs of Clindamycin ( $2 \mu \mathrm{g} /$ disc; Bioanalyse, Turkey) were used as positive control. The plates were incubated at $37^{\circ} \mathrm{C}$. Each test was performed in triplicate and the results were provided as mean values in $\mathrm{mm} \pm \mathrm{SD}$.

\section{Minimum inhibitory concentration (MIC) determination}

Broth microdilution method was used for the determination of minimum inhibitory concentration, according to CLSI methodology (2015), by the visual inspection of the microtiter plates (in two-fold dilutions) using a concave mirror for the absence of turbidity.

\section{Morphological analysis by Transmission Electron Microscope (TEM)}

The Streptococcus mutans suspension was photographed with and without the addition of MIC concentration of the nanoemulsion, on a carbon-coated copper grid using JEM 1200 EXII TEM, Jeol, Japan, operated at an accelerating voltage of $60-70 \mathrm{KV}$.

\section{Molecular modeling}

In-silico molecular modeling was done using Discovery Studio 2.5 software (Accelrys Inc., San Diego, CA, USA) and 
applying the C-Docker protocol. The X-ray crystal structure of the C-terminal region of a Streptococcus mutans surface protein antigen (PDB ID3QE5) co-crystallized with its ligand has been downloaded from the protein data bank. The program protein preparation protocol and CHARMm force field were applied then the C-Docker binding energy of the selected docking pose was calculated by the program.

\section{Statistical analyses}

The results were measured in triplicates and reported as the mean value \pm SD. The statistical analyses were made by unpaired $t$-test using GraphPad InStat 3 Software, Inc. La Jolla, CA, USA. The statistical significance level was set for all analyses at $P<0.05$.

\section{RESULTS AND DISCUSSION}

\section{Essential oil analysis}

Ninety compounds constituting $96.63 \%$ of the total peak area were identified in the ginger leaves oil by GC/MS analysis, as shown in Table 1, for the first time from the Egyptian chemotype. Methods for compounds identification were their experimental retention indices and mass spectra comparison with the $8^{\text {th }}$ edition of Wiley Registry of Mass Spectral Data, NIST Mass Spectral Library (December 2005), previously published literature (Ayoub et al., 2010; Singab et al., 2014; Mostafa et al., 2015; Mostafa et al., 2018) and/or authentic samples. The major components were oxygenated compounds from different classes (30.38\%), of which methyl cinnamate $(29.21 \%)$ represented the most abundant compound. Monoterpene hydrocarbons (23.83\%) represent the second major class of compounds, rich in $\beta$-pinene $(8.59 \%)$ and terpinolene $(7.46 \%)$. While sesquiterpene hydrocarbons reached $20.86 \%$, of which $\delta$-cadinene $(7.05 \%)$ was the major component.

A previous study done by Sivasothy et al. (2011) on $Z$. officinale var. rubrum Thielade from Malaysia identified forty-six compounds from the leaves oil. They have reported, in common with the present study, the abundance of high percentages of sesquiterpenoids (47.1\%), as well as monoterpenoids (42.6\%) in the leaves oil. $\beta$-caryophyllene represents the major component $(31.7 \%)$ in their study, while in the present study, $\beta$-caryophyllene was detected with only $2.17 \%$. However, our main oil component, methyl cinnamate (29.21\%), was not detected at all in their corresponding study. Of the major components identified in the present study; $\beta$-pinene, $\delta$-cadinene, and linalool were also identified in their leaves volatiles, but in much lower amounts representing only $2,0.3$ and $1.1 \%$, respectively. Sivasothy et al. (2011) didn't detect terpinolene in their leaves oil but they rather identified it in the rhizomes oil. These variations in the leaves oil composition between the two studies may be attributed to the source, method of cultivation, regional variations and the season of plant collection (Sari et al., 2006).

\section{Nanoemulsion characterization}

Determination of particle size, distribution, zeta potential and $\mathrm{pH}$

The nanoemulsion particles had a mean diameter of $151.4 \mathrm{~nm}$ and a polydispersity index of 0.27 , which indicate a homogenous formulation. The particle size distribution is presented in Figure 1. The mean zeta potential value was -13.75 $\pm 3.18 \mathrm{mV}$, this negative value may be explained by the use of a hydrophilic emulsifier, which is Tween- 80 with oxygen atoms in its molecule, that present a negative surface charge density (Flores et al., 2011). The mean $\mathrm{pH}$ value of a triplicate measurement of the formulation was 4 .

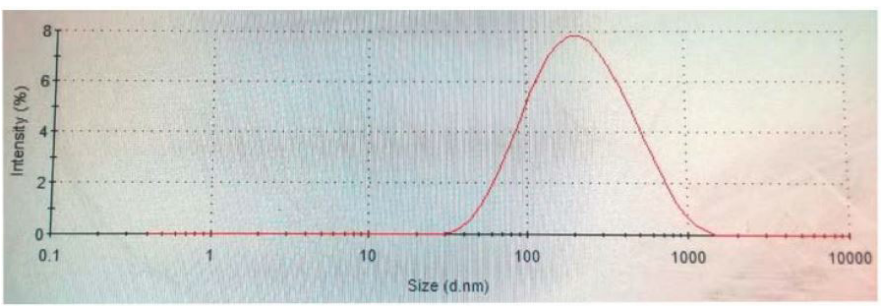

Fig. 1: Nanoemulsion particle size distribution by intensity.

\section{Nanoemulsion stability study}

The formulated nanoemulsion was kept in the refrigerator and tested for stability for a period of one month. The stability parameters are presented in Table 2 . The nanoemulsion was homogenous and consistent with no apparent phase separation when inspected visually. Non-significant changes in particle size diameter, polydispersity index, and zeta potential were observed after one-month storage $(P<0.05)$.

\section{Morphological analysis using transmission electron microscope (TEM)}

TEM examination of the nanoemulsion showed particles of almost spherical shape and confirmed the particles nanometric size, as shown in Figure 2. The particles size observed by TEM was much smaller than that measured by the photon correlation spectroscopy due to the drying process involved in the sample preparation for TEM imaging, thus the dried oil droplets in the core would appear smaller (Ishak et al., 2017; Nantarat et al., 2015).

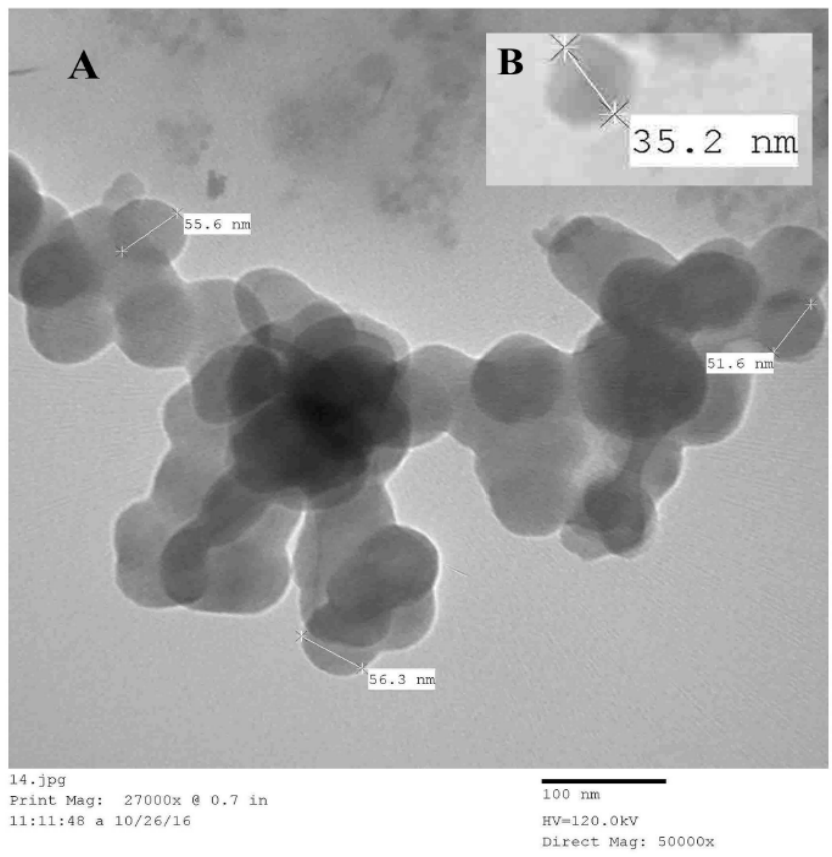

Fig. 2: Transmission electron microscope imaging showing (A) the nanoemulsion (sample magnification was 50000 times); (B) an individual droplet. 
Table 1: The chemical composition of ginger (Zingiber officinale) leaves volatile oil.

\begin{tabular}{|c|c|c|c|c|c|c|}
\hline & Compound $^{\text {a }}$ & RI $^{\mathrm{b}}$ calculated & RI reported & Composition $^{\mathrm{c}}(\%)$ & Molecular formula & Method of identification \\
\hline 1 & $\alpha$-Pinene & 927 & 929 & 1.84 & $\mathrm{C}_{10} \mathrm{H}_{16}$ & RI, MS, AU \\
\hline 2 & Camphene & 943 & 943 & 1.46 & $\mathrm{C}_{10} \mathrm{H}_{16}$ & RI, MS \\
\hline 3 & Benzaldehyde & 958 & 962 & 0.01 & $\mathrm{C}_{7} \mathrm{H}_{6} \mathrm{O}$ & RI, MS \\
\hline 4 & $\beta$-Pinene & 976 & 979 & 8.59 & $\mathbf{C}_{10} \mathbf{H}_{16}$ & RI, MS, AU \\
\hline 5 & $\beta$-Myrcene & 990 & 992 & 0.82 & $\mathrm{C}_{10} \mathrm{H}_{16}$ & RI, MS \\
\hline 6 & $\delta$-2-Carene & 1001 & 998 & 0.01 & $\mathrm{C}_{10} \mathrm{H}_{16}$ & RI, MS \\
\hline 7 & $\alpha$-Phellandrene & 1004 & 1007 & 0.34 & $\mathrm{C}_{10} \mathrm{H}_{16}$ & RI, MS, AU \\
\hline 8 & 3-Carene & 1010 & 1011 & 0.33 & $\mathrm{C}_{10} \mathrm{H}_{16}$ & RI, MS \\
\hline 9 & $\alpha$-Terpinene & 1017 & 1017 & 0.11 & $\mathrm{C}_{10} \mathrm{H}_{16}$ & RI, MS \\
\hline 10 & $m$-Cymene & 1023 & 1022 & 0.01 & $\mathrm{C}_{10} \mathrm{H}_{14}$ & RI, MS \\
\hline 11 & $p$-Cymene & 1025 & 1025 & 0.45 & $\mathrm{C}_{10} \mathrm{H}_{14}$ & RI, MS \\
\hline 12 & Limonene & 1030 & 1032 & 2.19 & $\mathrm{C}_{10} \mathrm{H}_{16}$ & $\mathrm{RI}, \mathrm{MS}, \mathrm{AU}$ \\
\hline 13 & Eucalyptol & 1032 & 1031 & 1.58 & $\mathrm{C}_{10} \mathrm{H}_{18} \mathrm{O}$ & RI, MS, AU \\
\hline 14 & cis- $\beta$-Ocimene & 1038 & 1037 & 0.01 & $\mathrm{C}_{10} \mathrm{H}_{16}$ & RI, MS \\
\hline 15 & trans- $\beta$-Ocimene & 1049 & 1050 & 0.02 & $\mathrm{C}_{10} \mathrm{H}_{16}$ & RI, MS \\
\hline 16 & $\gamma$-Terpinene & 1060 & 1060 & 0.15 & $\mathrm{C}_{10} \mathrm{H}_{16}$ & RI, MS \\
\hline 17 & Terpinolene & 1092 & 1089 & 7.46 & $\mathbf{C}_{10} \mathbf{H}_{16}$ & RI, MS \\
\hline 18 & 6-Camphenone & 1099 & 1093 & 0.01 & $\mathrm{C}_{10} \mathrm{H}_{14} \mathrm{O}$ & RI, MS \\
\hline 19 & $\beta$-Linalool & 1104 & 1100 & 3.04 & $\mathrm{C}_{10} \mathrm{H}_{18} \mathrm{O}$ & RI, MS, AU \\
\hline 20 & 2,9-Dimethyl-5-decyne & 1106 & 1103 & 0.2 & $\mathrm{C}_{12} \mathrm{H}_{22}$ & RI, MS \\
\hline 21 & 1,3,8-p-Menthatriene & 1114 & 1112 & 0.04 & $\mathrm{C}_{10} \mathrm{H}_{14}$ & RI, MS \\
\hline 22 & $\beta$-Fenchol & 1117 & 1117 & 0.02 & $\mathrm{C}_{10} \mathrm{H}_{18} \mathrm{O}$ & RI, MS \\
\hline 23 & $\alpha$-Campholenal & 1129 & 1124 & 0.01 & $\mathrm{C}_{10} \mathrm{H}_{16} \mathrm{O}$ & RI, MS \\
\hline 24 & trans-Pinocarveol & 1143 & 1140 & 0.05 & $\mathrm{C}_{10} \mathrm{H}_{16} \mathrm{O}$ & RI, MS \\
\hline 25 & Camphor & 1149 & 1143 & 1.37 & $\mathrm{C}_{10} \mathrm{H}_{16} \mathrm{O}$ & RI, MS \\
\hline 26 & Camphene hydrate & 1152 & 1149 & 0.13 & $\mathrm{C}_{10} \mathrm{H}_{18} \mathrm{O}$ & RI, MS \\
\hline 27 & Pinocarvone & 1166 & 1161 & 0.04 & $\mathrm{C}_{10} \mathrm{H}_{14} \mathrm{O}$ & RI, MS \\
\hline 28 & Borneol & 1170 & 1166 & 0.44 & $\mathrm{C}_{10} \mathrm{H}_{18} \mathrm{O}$ & RI, MS \\
\hline 29 & $p$-Cymen-8-ol & 1188 & 1182 & 0.21 & $\mathrm{C}_{10} \mathrm{H}_{14} \mathrm{O}$ & RI, MS \\
\hline 30 & $\alpha$-Terpineol & 1194 & 1190 & 0.21 & $\mathrm{C}_{10} \mathrm{H}_{18} \mathrm{O}$ & RI, MS \\
\hline 31 & Myrtenal & 1200 & 1192 & 0.13 & $\mathrm{C}_{10} \mathrm{H}_{14} \mathrm{O}$ & RI, MS \\
\hline 32 & trans-Piperitol & 1211 & 1205 & Tr. & $\mathrm{C}_{10} \mathrm{H}_{18} \mathrm{O}$ & RI, MS \\
\hline 33 & Fenchyl acetate & 1223 & 1219 & 0.06 & $\mathrm{C}_{12} \mathrm{H}_{20} \mathrm{O}_{2}$ & RI, MS \\
\hline 34 & cis-Carveol & 1227 & 1229 & 0.05 & $\mathrm{C}_{10} \mathrm{H}_{16} \mathrm{O}$ & RI, MS \\
\hline 35 & Neral & 1245 & 1242 & 0.04 & $\mathrm{C}_{10} \mathrm{H}_{16} \mathrm{O}$ & RI, MS \\
\hline 36 & Linalyl acetate & 1251 & 1255 & 0.06 & $\mathrm{C}_{12} \mathrm{H}_{20} \mathrm{O}_{2}$ & RI, MS \\
\hline 37 & trans-2-Decenal & 1260 & 1263 & 0.37 & $\mathrm{C}_{10} \mathrm{H}_{18} \mathrm{O}$ & RI, MS \\
\hline 38 & Geranial & 1276 & 1270 & 0.05 & $\mathrm{C}_{10} \mathrm{H}_{16} \mathrm{O}$ & RI, MS \\
\hline 39 & trans-Cinnamaldehyde & 1277 & 1271 & 0.07 & $\mathrm{C}_{9} \mathrm{H}_{8} \mathrm{O}$ & RI, MS \\
\hline 40 & Methyl hydrocinnamate & 1281 & 1280 & 0.18 & $\mathrm{C}_{10} \mathrm{H}_{12} \mathrm{O}_{2}$ & RI, MS \\
\hline 41 & Bornyl acetate & 1292 & 1291 & 0.08 & $\mathrm{C}_{12} \mathrm{H}_{20} \mathrm{O}_{2}$ & RI, MS \\
\hline 42 & 2-Undecanone & 1297 & 1293 & 0.05 & $\mathrm{C}_{11} \mathrm{H}_{22} \mathrm{O}$ & RI, MS \\
\hline 43 & (Z)-Methyl cinnamate & 1305 & 1300 & 0.62 & $\mathrm{C}_{10} \mathrm{H}_{10} \mathrm{O}_{2}$ & RI, MS \\
\hline 44 & $(E, E)$-2,4-Decadienal & 1321 & 1318 & 0.05 & $\mathrm{C}_{10} \mathrm{H}_{16} \mathrm{O}$ & RI, MS \\
\hline 45 & Myrtenyl acetate & 1331 & 1329 & 0.07 & $\mathrm{C}_{12} \mathrm{H}_{18} \mathrm{O}_{2}$ & RI, MS \\
\hline 46 & $\alpha$-Cubebene & 1355 & 1351 & 0.52 & $\mathrm{C}_{15} \mathrm{H}_{24}$ & RI, MS \\
\hline 47 & $\alpha$-Copaene & 1381 & 1377 & 0.82 & $\mathrm{C}_{15} \mathrm{H}_{24}$ & RI, MS \\
\hline 48 & Methyl cinnamate & 1400 & 1399 & 29.21 & $\mathrm{C}_{10} \mathrm{H}_{10} \mathrm{O}_{2}$ & RI, MS \\
\hline 49 & $\beta$-Caryophyllene & 1430 & 1428 & 2.17 & $\mathrm{C}_{15} \mathrm{H}_{24}$ & RI, MS, AU \\
\hline 50 & $\gamma$-Elemene & 1435 & 1436 & 0.02 & $\mathrm{C}_{15} \mathrm{H}_{24}$ & RI, MS \\
\hline
\end{tabular}




\begin{tabular}{|c|c|c|c|c|c|c|}
\hline 51 & trans- $\alpha$-Bergamotene & 1442 & 1436 & 0.19 & $\mathrm{C}_{15} \mathrm{H}_{24}$ & RI, MS \\
\hline 52 & $\alpha$-Guaiene & 1446 & 1440 & 0.32 & $\mathrm{C}_{15} \mathrm{H}_{24}$ & RI, MS \\
\hline 53 & Aristolene & 1452 & 1450 & 2.07 & $\mathrm{C}_{15} \mathrm{H}_{24}$ & RI, MS \\
\hline 54 & $\beta$-Chamigrene & 1458 & 1451 & 0.45 & $\mathrm{C}_{15} \mathrm{H}_{24}$ & RI, MS \\
\hline 55 & $\alpha$-Humulene & 1464 & 1457 & 0.72 & $\mathrm{C}_{15} \mathrm{H}_{24}$ & RI, MS \\
\hline 56 & Alloaromadendrene & 1471 & 1465 & 0.69 & $\mathrm{C}_{15} \mathrm{H}_{24}$ & RI, MS \\
\hline 57 & $\delta$-Selinene & 1485 & 1485 & 1.09 & $\mathrm{C}_{15} \mathrm{H}_{24}$ & RI, MS \\
\hline 58 & Germacrene D & 1492 & 1490 & 0.27 & $\mathrm{C}_{15} \mathrm{H}_{24}$ & RI, MS \\
\hline 59 & $\beta$-Eudesmene & 1495 & 1490 & 0.39 & $\mathrm{C}_{15} \mathrm{H}_{24}$ & RI, MS \\
\hline 60 & $\alpha$-Selinene & 1498 & 1498 & 0.51 & $\mathrm{C}_{15} \mathrm{H}_{24}$ & RI, MS \\
\hline 61 & $\alpha$-Bulnesene & 1500 & 1504 & 0.40 & $\mathrm{C}_{15} \mathrm{H}_{24}$ & RI, MS \\
\hline 62 & Valencene & 1506 & 1503 & 1.81 & $\mathrm{C}_{15} \mathrm{H}_{24}$ & RI, MS \\
\hline 63 & $\alpha$-Muurolene & 1510 & 1509 & 0.92 & $\mathrm{C}_{15} \mathrm{H}_{24}$ & RI, MS \\
\hline 64 & Selina-3,7(11)-diene & 1530 & 1532 & 0.38 & $\mathrm{C}_{15} \mathrm{H}_{24}$ & RI, MS \\
\hline 65 & $\delta$-Cadinene & 1536 & 1530 & 7.05 & $\mathrm{C}_{15} \mathrm{H}_{24}$ & RI, MS \\
\hline 66 & $\alpha$-Cadinene & 1547 & 1546 & 0.07 & $\mathrm{C}_{15} \mathrm{H}_{24}$ & RI, MS \\
\hline 67 & trans-Nerolidol & 1571 & 1564 & 2.31 & $\mathrm{C}_{15} \mathrm{H}_{26} \mathrm{O}$ & RI, MS \\
\hline 68 & Globulol & 1585 & 1582 & 1.18 & $\mathrm{C}_{15} \mathrm{H}_{26} \mathrm{O}$ & RI, MS \\
\hline 69 & Spathulenol & 1590 & 1591 & 1.19 & $\mathrm{C}_{15} \mathrm{H}_{24} \mathrm{O}$ & RI, MS \\
\hline 70 & Viridiflorol & 1596 & 1591 & 1.18 & $\mathrm{C}_{15} \mathrm{H}_{24} \mathrm{O}$ & RI, MS \\
\hline 71 & Cubedol & 1610 & & 2.22 & $\mathrm{C}_{15} \mathrm{H}_{26} \mathrm{O}$ & MS \\
\hline 72 & $\gamma$-eudesmol & 1634 & 1631 & 0.28 & $\mathrm{C}_{15} \mathrm{H}_{26} \mathrm{O}$ & RI, MS \\
\hline 73 & $\alpha$-Cadinol & 1655 & 1653 & 1.95 & $\mathrm{C}_{15} \mathrm{H}_{26} \mathrm{O}$ & RI, MS \\
\hline 74 & 7(11)-Selinen-4- $\alpha$-ol & 1676 & 1675 & 0.38 & $\mathrm{C}_{15} \mathrm{H}_{26} \mathrm{O}$ & RI, MS \\
\hline 75 & Bulnesol & 1683 & 1678 & 1.07 & $\mathrm{C}_{15} \mathrm{H}_{26} \mathrm{O}$ & RI, MS \\
\hline 76 & $(E, E)$-Farnesal & 1749 & 1741 & 0.02 & $\mathrm{C}_{15} \mathrm{H}_{24} \mathrm{O}$ & RI, MS \\
\hline 77 & $n$-Octadecane & 1797 & 1800 & 0.01 & $\mathrm{C}_{18} \mathrm{H}_{38}$ & RI, MS \\
\hline 78 & Isopropyl myristate & 1825 & 1827 & 0.02 & $\mathrm{C}_{17} \mathrm{H}_{34} \mathrm{O}_{2}$ & RI, MS \\
\hline 79 & Hexahydrofarnesyl acetone & 1846 & 1848 & 0.01 & $\mathrm{C}_{18} \mathrm{H}_{36} \mathrm{O}$ & RI, MS \\
\hline 80 & $n$-Hexadecanol & 1882 & 1880 & 0.02 & $\mathrm{C}_{16} \mathrm{H}_{34} \mathrm{O}$ & RI, MS \\
\hline 81 & $\mathrm{n}$-Nonadecane & 1899 & 1900 & 0.02 & $\mathrm{C}_{19} \mathrm{H}_{40}$ & RI, MS \\
\hline 82 & $(E, E)$-Farnesyl acetone & 1923 & 1922 & 0.08 & $\mathrm{C}_{18} \mathrm{H}_{30} \mathrm{O}$ & RI, MS \\
\hline 83 & Palmitic acid & 1965 & 1961 & 0.01 & $\mathrm{C}_{16} \mathrm{H}_{32} \mathrm{O}_{2}$ & RI, MS, AU \\
\hline 84 & (Z)-9-Octadecenal & 1996 & 1995 & 0.02 & $\mathrm{C}_{18} \mathrm{H}_{34} \mathrm{O}$ & RI, MS \\
\hline 85 & Octadecanal & 2022 & 2021 & 0.20 & $\mathrm{C}_{18} \mathrm{H}_{36} \mathrm{O}$ & RI, MS \\
\hline 86 & Phytol & 2122 & 2116 & 1.18 & $\mathrm{C}_{20} \mathrm{H}_{40} \mathrm{O}$ & RI, MS \\
\hline 87 & $n$-Tricosane & 2301 & 2300 & 0.05 & $\mathrm{C}_{23} \mathrm{H}_{48}$ & RI, MS \\
\hline 88 & $n$-Tetracosane & 2395 & 2400 & 0.04 & $\mathrm{C}_{24} \mathrm{H}_{50}$ & RI, MS \\
\hline 89 & $n$-Hexacosane & 2601 & 2600 & 0.02 & $\mathrm{C}_{26} \mathrm{H}_{54}$ & RI, MS \\
\hline 90 & $n$-Heptacosane & 2699 & 2700 & 0.07 & $\mathrm{C}_{27} \mathrm{H}_{56}$ & RI, MS \\
\hline Total & & & & $96.63 \%$ & & \\
\hline
\end{tabular}

${ }^{\mathrm{a}}$ Compounds are listed according to elution order, RI ${ }^{\mathrm{b}}$ Kovats retention index calculated on Rtx-5MS fused bonded column, ${ }^{\mathrm{c}}$ Average of three analyses. MS, mass spectral data; RI, published retention indices; AU, co-chromatography with authentics, Tr., traces $<0.01$. The major components are bold highlighted.

\section{Antimicrobial activity}

\section{Inhibition zone and MIC determinations}

The mean inhibition zone diameters (of three measurements) of the nanoemulsion and the clindamycin disc (2 $\mu \mathrm{g} / \mathrm{disc})$ are shown in Table 3 . No growth inhibition was observed in the control well (Tween- 80 in water at the same used concentration). MIC value of the nanoemulsion was $62.5 \mu \mathrm{L} / \mathrm{mL}$ that is equivalent to $0.61 \mu \mathrm{L} / \mathrm{mL}$ of pure essential oil.

\section{Morphological analysis by TEM}

The impact of ginger leaves nanoemulsion on the destruction of the biofilm integrity of $S$. mutans was illustrated by TEM, as shown in Figure 3. The control of bacterial suspension showed cells aggregation and clumping with a chainforming pattern. While, the bacterial suspension treated with the nanoemulsion (at its MIC level) showed significant cells scattering and dispersion without any apparent chain formation, suggesting 
reduced $S$. mutans glucan synthesis, which is required for bacterial adherence (Hasan et al., 2015), also the cells scattering has resulted in reduced cells interaction and impaired formation of the bacterial biofilm.

Table 2: Stability study parameters of the prepared nanoemulsion.

\begin{tabular}{cccc}
\hline Days & $\begin{array}{c}\text { Particle size }(\mathbf{n m}) \\
(\mathbf{m e a n} \pm \mathbf{S D})\end{array}$ & $\begin{array}{c}\text { Polydispersity index } \\
(\mathbf{m} \text { )an } \pm \text { SD) }\end{array}$ & $\begin{array}{c}\text { Zeta potential }(\mathbf{m V}) \\
(\text { mean } \pm \text { SD) }\end{array}$ \\
\hline Day 0 & $151.4 \pm 17.38$ & $0.268 \pm 0.003$ & $-13.75 \pm 3.18$ \\
Day 14 & $153.8 \pm 11.99$ & $0.263 \pm 0.017$ & $-14.6 \pm 0.62$ \\
Day 30 & $157.6 \pm 16.26$ & $0.258 \pm 0.030$ & $-10.47 \pm 1.18$ \\
\hline
\end{tabular}

All measurements are done in triplicates.

Table 3: Antibacterial activity of ginger leaves oil nanoemulsion against $S$. mutans.

\begin{tabular}{ccc}
\hline Tested sample & $\begin{array}{c}\text { Inhibition zone diameter }(\mathbf{m m}) \\
(\mathbf{m e a n} \pm \mathbf{S D}) *\end{array}$ & MIC $(\boldsymbol{\mu L} / \mathbf{m L})$ \\
\hline Nanoemulsion $(100 \mu \mathrm{L})$ & $25 \pm 1.0$ & 62.5 \\
Clindamycin $(2 \mu \mathrm{g} /$ disc $)$ & $30 \pm 0.5$ & $\mathrm{NT}$ \\
Blank control $(100 \mu \mathrm{L})$ & $0 \pm 0.0$ & $\mathrm{NT}$ \\
\hline
\end{tabular}

*Values for three determinations; NT: not tested.

\section{Docking study}

The molecular docking was done to evaluate the possible binding mode of methyl cinnamate (the major volatile component, $29.21 \%$ ) to the active site of the C-terminal region of $S$. mutans surface protein antigen (Ag I/II). Inspection of the active site of the bacterial protein surface antigen revealed many amino acids, such as Glu 1215, Glu 1216, Lys1299 and Thr 1244, which stabilize the complex of methyl cinnamate with the protein. The C-Docker binding energy of the selected docking pose was $-8.239 \mathrm{kcal} / \mathrm{mol}$. The 2D- and 3D-binding modes of methyl cinnamate are shown in Figure 4, where methyl cinnamate showed a good binding affinity to the bacterial surface protein antigen through a $P i-P i$ interaction between the benzene ring of the ligand and the Lys 1299 residue of the protein, besides four hydrophobic interactions of the ligand with the protein active site. This indicates a high inhibitory activity of $S$. mutans surface protein antigen.

The docking results of methyl cinnamate (ginger leaves oil major component) were comparable to those reported for eugenol (the major clove oil component) on S. mutans surface antigen (Ag I/II) (Adil, 2013), where the amino acid residues Glu 1215 and Glu 1216 were common in stabilizing the complex formed for either compound. Moreover, eugenol bondings with the protein active site were through hydrophobic interactions as for methyl cinnamate, in addition to H-bonding.

Eugenol had been used extensively as an antiseptic, reported for its antibacterial activity against $S$. mutans (Freires et al., 2015), used in dentistry as a base for fillings, and as a cement component for sealing cavities (Souza-Costa et al., 2007). On the other side, methyl cinnamate has been used in many foods, pharmaceutical industries and cosmetic products (Bathia et al., 2007). According to the results declared by the Joint FAO/WHO Expert Committee on Food Additives (JECFA) and the European Food Safety Authority (EFSA, 2009), methyl cinnamate intake is considered safe at the levels of use as a flavoring agent. Thus, further studies should be carried out to study the possible use of the ginger oil rich in methyl cinnamate or the pure compound in dentistry clinical applications.
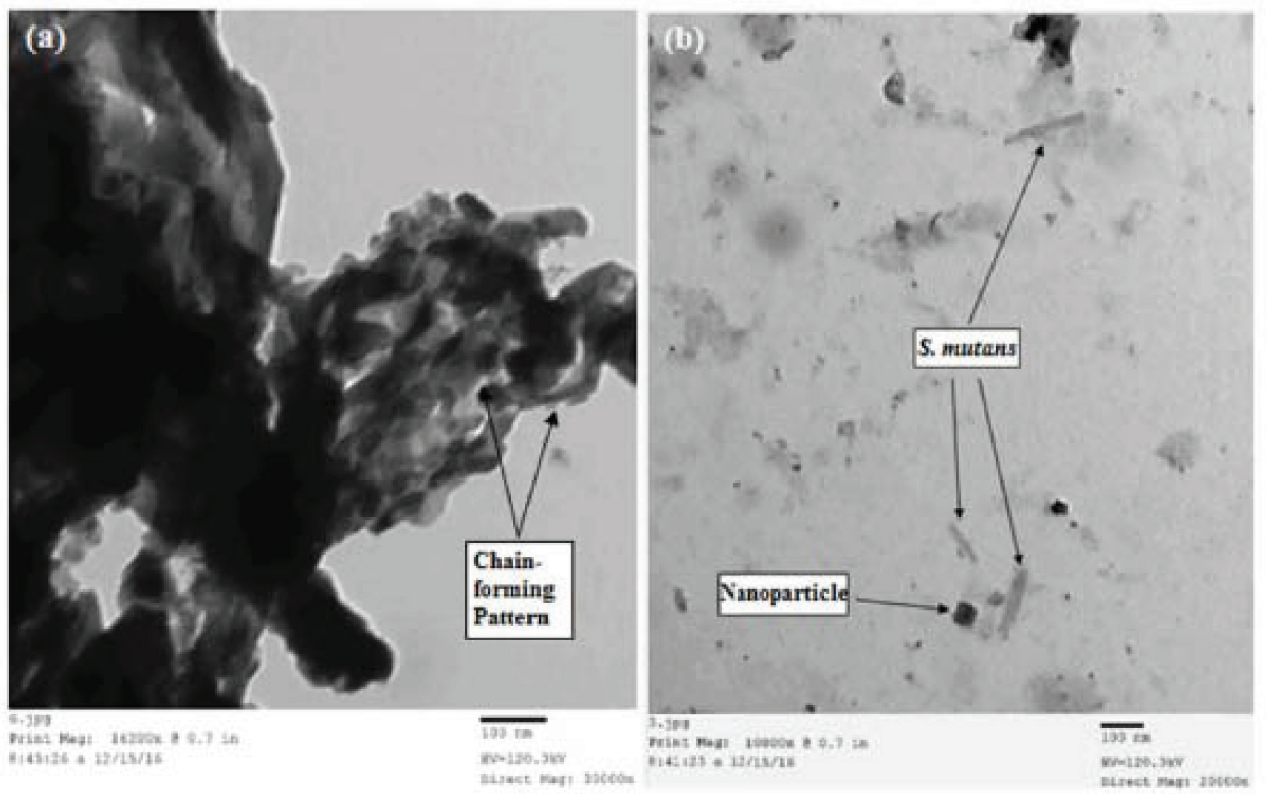

Fig. 3: Transmission electron microscope imaging of (a) Streptococcus mutans suspension alone showing biofilm and chain-forming aggregates, and (b) nanoemulsion (at MIC level) and S. mutans showing impairment of bacterial biofilm integrity. Samples magnifications were 30000 and 20000 times, respectively.

\section{CONCLUSION}

Ginger (Zingiber officinale Roscoe) leaves volatile oil is rich in valuable phytoconstituents; the oil nanoemulsion formulation was stable, effective on Streptococcus mutans, and can be further studied for use as a gargle against dental caries and plaque formation. 

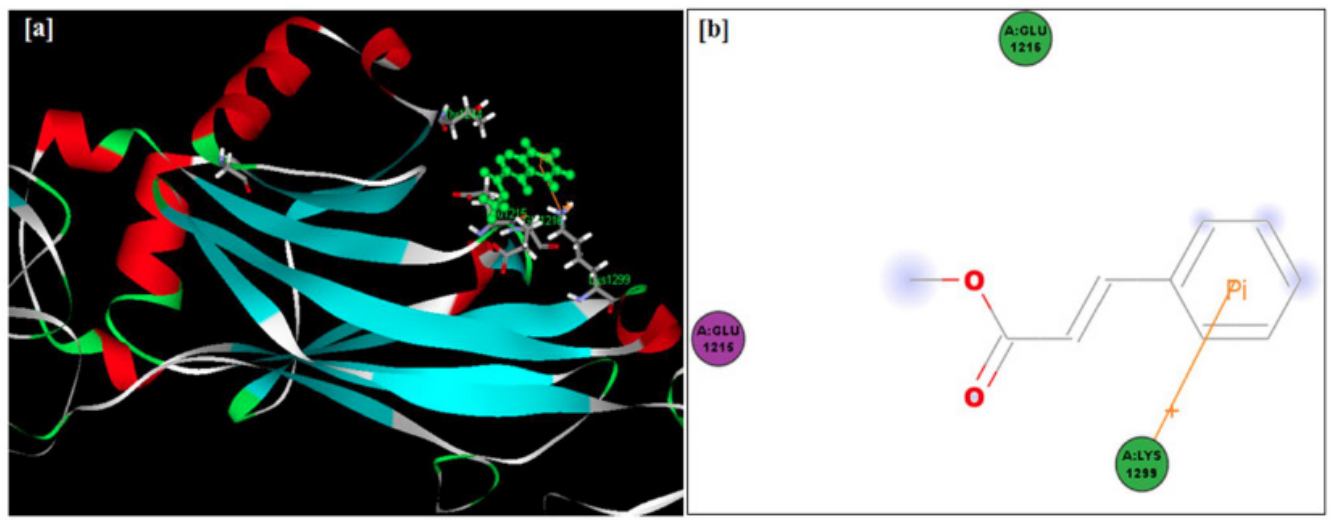

Fig. 4: Binding of methyl cinnamate to the active C-terminal region of S. mutans surface protein antigen in [a] 3D-diagram and [b] 2D-diagram.

\section{CONFLICT OF INTERESTS}

The author declares no conflict of interest.

\section{ACKNOWLEDGMENTS}

Thanks to Dr. Samar Samir, Lecturer of Microbiology, Faculty of Science, Ain Shams University, Cairo, Egypt, for her kind help in the antibacterial activity assessment.

\section{REFERENCES}

Abdel-Azeem AS, Hegazy AM, Ibrahim KS, Farrag AR, ElSayed EM. Hepatoprotective, antioxidant, and ameliorative effects of ginger (Zingiber officinale Roscoe) and vitamin $\mathrm{E}$ in acetaminophen treated rats. J Diet Suppl, 2013; 10:195-209.

Adil M (Ph. D thesis). 2013. Characterization of anti-biofilm and anti-adherent compounds against Streptococcus mutans from medicinal plants, Interdisciplinary Biotechnology Unit, Aligarh Muslim University, India.

Amaral DMF, Bhargava K. Essential oil nanoemulsions and food applications. Adv Food Technol Nutr Sci Open J, 2015; 1:84-87.

Ayoub N, Singab AN, Mostafa N, Schultze W. Volatile constituents of leaves of Ficus carica Linn. grown in Egypt. J Essent Oil Bear Pl, 2010; 13:316-321.

Bhatia SP, Wellington GA, Cocchiara J, Lalko J, Letizia CS, Api AM. Fragrance material review on methyl cinnamate. Food Chem Toxicol, 2007; 45 Suppl 1:S113-119.

Clinical and Laboratory Standards Institute (CLSI). 2015. Methods for dilution antimicrobial susceptibility tests for bacteria that grow aerobically, approved standard-Tenth edition, M07-A10. Wayne, PA.

Clinical and Laboratory Standards Institute (CLSI). 2013. Performance standards for antimicrobial susceptibility testing, Disc diffusion supplemental tables, M100-S23 (M02-A11). Wayne, PA.

EFSA; Scientific Opinion on Flavouring Group Evaluation 68 (FGE.68): Consideration of cinnamyl alcohol and related flavouring agents evaluated by JECFA (55th meeting) structurally related to aryl-substituted saturated and unsaturated primary alcohol/aldehyde/acid/ester derivatives evaluated by EFSA in FGE.15Rev1 (2008). EFSA Journal, 2009; 7:1032.

Flores FC, Ribeiro RF, Ourique AF, Rolim CMB, Silva CB, Pohlmann AR, Beck RCR, Guterres SS. Nanostructured systems containing an essential oil: protection against volatilization. Quim Nova, 2011; 34:968972 .

Freires IA, Denny C, Benso B, de Alencar SM, Rosalen PL. Antibacterial activity of essential oils and their isolated constituents against cariogenic bacteria: A systematic review. Molecules, 2015; 20:7329-7358.

Hasan S, Danishuddin M, Khan AU. Inhibitory effect of Zingiber officinale towards Streptococcus mutans virulence and caries development: in vitro and in vivo studies. BMC Microbiol, 2015; 15:1.
Hasan S, Singh K, Danisuddin M, Verma PK, Khan AU. Inhibition of major virulence pathways of Streptococcus mutans by quercitrin and deoxynojirimycin: A synergistic approach of infection control. PLoS One, 2014; 9:e91736.

Ishak RAH, Mostafa NM, Kamel AO. Stealth lipid polymer hybrid nanoparticles loaded with rutin for effective brain delivery comparative study with the gold standard (Tween 80): optimization, characterization and biodistribution, Drug Deliv, 2017; 24:1874-1890.

Jeena K, Liju VB, Kuttan R. Antioxidant, anti-inflammatory and antinociceptive activities of essential oil from ginger. Indian J Physiol Pharmacol, 2013; 57:51-62.

Krzyściak W, Jurczak A, Kościelniak D, Bystrowska B, Skalniak A. The virulence of Streptococcus mutans and the ability to form biofilms. Eur J Clin Microbiol Infect Dis, 2014; 33:499-515.

Loesche WJ. Role of Streptococcus mutans in human dental decay. Microbiol Rev, 1986; 50:353-380.

Manconi M, Sinico C, Caddeo C, Vila AO, Valenti D, Fadda AM Penetration enhancer containing vesicles as carriers for dermal delivery of tretinoin. Int J Pharm, 2011; 412:37-46.

Mostafa NM. $\beta$-Amyrin rich Bombax ceiba leaf extract with potential neuroprotective activity against scopolamine-induced memory impairment in rats. Rec Nat Prod, 2018; 12:480-492.

Mostafa NM, Eldahshan OA, Singab AB. Chemical composition and antimicrobial activity of flower essential oil of Jacaranda acutifolia Humb. and Bonpl. against food-borne pathogens. European J Med Plants, 2015; 6:62-69.

Mostafa NM, Singab AN. After HCV eradication with Sovaldi ${ }^{\circledR}$, can herbs regenerate damaged liver, minimize side effects and reduce the bill? Med Aromat Plants, 2016; 5:257.

Nantarat T, Chansakaow S, Leelapornpisid P. Optimization, characterization and stability of essential oils blend loaded nanoemulsions by PIC technique for anti-tyrosinase activity. Int J Pharm Pharm Sci, 2015; $7: 1491$.

Nielsen CK, Kjems J, Mygind T, Snabe T, Meyer RL. Effects of Tween 80 on growth and biofilm formation in laboratory media. Front Microbiol, 2016; 7:1878.

Salama HH, El-Sayed MM, El-Salam MH. Preparation of $\beta$-carotene enriched nanoemulsion by spontaneous emulsification using oleic acid as nano carrier. Res J Pharm Biol Chem Sci, 2016; 7:585-593.

Sari M, Biondi DM, Kaabeche M, Mandalari G, D'Arrigo M, Bisignano G. Chemical composition, antimicrobial and antioxidant activities of the essential oil of several populations of Algerian Origanum glandulosum Desf. Flavour Fragr J, 2006; 21:890-898.

Singab AB, Mostafa NM, Eldahshan OA, Ashour ML, Wink M. Profile of volatile components of hydrodistilled and extracted leaves of Jacaranda acutifolia and their antimicrobial activity against foodborne pathogens. Nat Prod Commun, 2014; 9:1007-1010. 
Sivasothy Y, Chong WK, Abdul Hamid, Eldeen IM, Sulaiman SF, Awang K. Essential oils of Zingiber officinale var. rubrum Theilade and their antibacterial activities. Food Chem, 2011; 124:514-517.

Souza-Costa CA, Teixeira HM, Nascimento ABL, Hebling J. Biocompatibility of resin-based dental materials applied as liners in deep cavities prepared in human teeth. J Biomed Mater Res B, 2007; 81:175-184. Yang Z, Yang W, Peng Q, He Q, Feng Y, Luo S, Yu Z. Volatile phytochemical composition of rhizome of ginger after extraction by headspace solid-phase microextraction, petroleum ether extraction and steam distillation extraction. Bangladesh J Pharmacol, 2009; 4:136-143.

How to cite this article:

Mostafa NM. Antibacterial Activity of Ginger (Zingiber officinale) Leaves Essential Oil Nanoemulsion against the Cariogenic Streptococcus mutans. J App Pharm Sci, 2018; 8(09): 034-041. 